\title{
SAUdAÇÃo PROFERIDA PELA PROFESSORA ADA PELLEGRINI GRINOVER A NOVA TITULAR, PROFESSORA IVETTE SENISE FERREIRA
}

Escolhida pela nova Professora Titular Ivette Senise Ferreira para dar-lhe as boas-vindas em nome da Faculdade de Direito da Universidade de São Paulo, tomo essa honrosa indicação como manifestação de afeto e de reconhecimento de tantos pontos comuns em nossas vidas.

Conhecemo-nos, Professora Ivette, nesta Faculdade, no curso que nos trouxe aos bancos acadêmicos, vós, vinda da natal Catanduva e eu, da mais longínqua Itália, em 1953. Logo nos identificamos, pelas origens comuns e pela afinidade de propósitos, tornando-nos amigas. Uniam-nos os mesmos ideais, os mesmos interesses. Fizemo-nos companheiras de estudos, de lazer e até de esporte. Dividimos livros e viagens, estudos e diversão, acalentando, com trepidação, o mesmo sonho: ocupar um dia, por mais longínquo que fosse, o lugar de nossos mestres. Até o amor chegou junto a nossos corações de vinte anos, e juras de amor eterno fizemos perante o altar no mesmo ano de 1957.

O casamento com o Professor Manoel Gonçalves Ferreira Filho, também colega de turma, levou-vos à França e lá cursastes o doutorado em Direito Penal e a Especialização em Criminologia na Faculdade de Direito da Universidade de Paris, em 1958 e 1959. O nascimento da pequena Beatriz - com quem brincamos, os quatro, nas neves de Montrouge - não vos permitiu concluir o curso, mas vosso destino já estava traçado. De retorno ao Brasil, outras três filhas vieram - Mônica, Marta, e Lígia - e por algum tempo vos concentrastes apenas na advocacia e em vossas meninas. O mesmo acontecia comigo, com o nascimento de Lamberto, e ambas tívemos que deixar de lado, enquanto as crianças cresciam, o sonho maior de nossas vidas: a carreira universitária.

Mas, logo que pudemos, e também ao mesmo tempo, retomamos os estudos em nível de pós-graduação, quando vossa versatilidade vos fez cursar, a partir de 1966, os cursos de especialização em Organizações Internacionais, Internacional Privado, História das Idéias Políticas e Direito Constitucional Comparado. E de novo ao mesmo tempo iniciamos as atividades docentes, ambas na Faculdade de Direito da Pontifícia Universidade Católica, eu como assistente do 
Professor Manoel Gonçalves Ferreira Filho, em Direito Constitucional, e vós como assistente do Professor André Franco Montoro, em Introdução à Ciência do Direito.

Mas a vocação pelo Direito Penal vos reconduziria à primeira disciplina que havíeis escolhido, quando, por vossos indiscutiveis méritos, em boa hora reconhecidos pelo Professor Paulo José da Costa Júnior, as portas do Departamento de Direito Penal da nossa Escola, que não mais deixaríeis, se abriram para a auxiliar de ensino, em 1971. Retomastes, a partir de 1976, o Curso de Doutorado em Direito Penal, concluído em 1982 com a defesa da tese $O$ Aborto Legal. E, a partir dai, fostes construindo, passo a passo, a árdua mas gratificante carreira universitária, conquistando primeiro a Livre-Docência, em 1988, com a tese Concurso Eventual de Pessoas, depois o título de Professor Associado, e finalmente a cátedra, que vos traz hoje aqui.

Durante todos esses anos vos dedicastes, com afinco e denodo, à edificação de vosso sólido saber científico, com verdadeiro espírito universitário, que vos empenhou na pesquisa, na docência e nos serviços à comunidade. Publicastes inúmeros artigos em revistas especializadas, brasileiras e estrangeiras; acumulastes o ensino nesta Casa, em nível de graduação e pós-graduação, com a docência do Direito Penal no Curso das Faculdades Metropolitanas Unidas; integrastes várias Bancas de Mestrado na nossa Faculdade e em outras, como a da Pontifícia Universidade Católica e da Universidade Mackenzie; orientastes alunos da pós-graduação e estudantes da graduação, em suas bolsas de iniciação científica; participastes de diversos Congressos, nacionais e internacionais, sempre com trabalhos apresentados; compusestes os Conselhos Estaduais de Promoção Social do Menor e do Bem-Estar do Menor, assim como o Conselho Deliberativo do Instituto Oscar Freire, depois Instituto de Medicina Social e Criminologia e o Conselho Técnico do Centro de Recursos Humanos da Administração Penitenciária da Secretaria da Justiça, posteriormente da Secretaria da Segurança Pública; participastes ativamente, em colegiados, da vida acadêmica desta Casa, que hoje representais junto ao Conselho de Cultura e Extensão Universitária da Universidade de São Paulo, inclusive pela integração de suas Câmaras. Fostes fundadora do Instituto Manoel Pedro Pimentel, que hoje secretariais. E jamais esquecestes vossa condição de mulher atuante e combativa, como membro do Conselho Nacional da Federação das Associações de Mulheres de Negócios e Profissionais do Brasil e do Conselho Consultivo da Associação Brasileira das Mulheres de Carreira Jurídica. 
Aliás, fostes escolhida a profissional de direito do ano de 1994, por esta Associação, oportunidade em que vossos méritos foram enaltecidos, em discurso emocionado, por outra mulher que abrilhantou esta Casa, a Professora Esther de Figueiredo Ferraz.

Toda vossa vida, todas vossas atividades põem de realce as multifárias facetas da personalidade harmoniosa de uma mulher integrada na sociedade em que vive e pela qual se sente tão responsável quanto o homem; os vossos méritos de educadora atenta e responsável e de pesquisadora intelectualmente inquieta, como devem ser os verdadeiros cientistas para que cresçam cada vez mais, aceitando e vencendo os desafios criados constantemente por suas mentes privilegiadas. E exemplo eloqüente de vossa cultura plurivalente são os temas a que dedicastes ultimamente vossas atenções: o vandalismo e a violência, a tutela penal do consumidor, a proteção da intimidade, os crimes da informática, as sanções penais por violações a direitos autorais, o direito penal ambiental. Mas o melhor exemplo da profundidade e da riqueza de vossos conhecimentos, que se centram no direito penal mas que não olvidam outros ramos da ciência jurídica, é a tese de cátedra $A$ Tutela Penal do Patrimônio Cultural.

Trata-se de trabalho de amplíssimo fôlego, de caráter nitidamente interdisciplinar, que vai além da tutela penal do patrimônio cultural, para cuidar da tutela do ambiente, lato sensu, em todos os seus aspectos: a internacional, a constitucional, a civil, a processual e, finalmente, a penal.

Escrevestes, Professora Ivette, uma obra completa de Direito Ambiental, essa generosa disciplina que se preocupa em cunhar instrumentos jurídicos de proteção contra a crescente degradação dos bens e valores naturais e culturais, de modo a preservar desde a qualidade de vida até sua própria manutenção no planeta Terra. E percebestes com toda clareza o tratamento, amplo e interdisciplinar, necessário à construção do direito penal ambiental - incipiente entre nós para, numa visão de conjunto, extrair do conceito global de patrimônio ambiental e dos diversos tipos de tutela a ele destinados pelos distintos ramos do direito o regime indispensável à adequada tutela penal do patrimônio natural e cultural.

A política ambiental, traçada em recomendações da comunidade internacional e delineada com clareza na Constituição de 1988 , deve nortear toda a 
legislação brasileira, orientando o legislador na elaboração da nova normação, assim como o intérprete, no tocante à legislação em vigor, numa exegese aderente ao perfil institucional imposto pela Lei Maior. Até porque o substrato filosófico da legislação anterior já havia sido posto em cheque pela ampla discussão dos problemas ambientais, pela atuação dos organismos internacionais, pelas atividades de associações civis, pelas pesquisas e pelos estudos científicos. De modo que a Constituição brasileira veio inserir-se no filão mais atual das linhas evolutivas do direito ambiental contemporâneo, dando respaldo político e jurídico às novas ações ambientais.

E para que estas sejam empreendidas sem demora, é preciso compreender o fenômeno ambiental em sua globalidade, para daí descer a seu tratamento, primeiro no plano internacional e depois no plano interno, procedendo à profunda análise de sua abordagem nas diversas disciplinas jurídicas, para somente depois ingressar na tutela penal do patrimônio cultural.

É exatamente isso que fizestes, com toda a maestria, fornecendo ao legislador e ao intérprete os dados necessários à reformulação e à releitura da legislação ambiental vigente, e notadamente à construção de normas penais adequadas, de modo a propiciar os meios e instrumentos necessários para que não caiam no vazio os preceitos do art. 225 da Constituição de 1988.

Por isso, e por tantas outras razões, minha querida Professora, eu vos saúdo, com carinho emocionado, como legítima representante das mais lídimas esperanças de uma nova cultura jurídica nesta velha Academia. E, com respeito e alegria, toda a Faculdade vos acolhe: vossos colegas de magistério, vossas alunos, o corpo administrativo, toda a comunidade acadêmica, enfim, recebe de braços abertos a nova Titular de Direito Penal, na certeza de conquistas sempre maiores, para a glória desta Casa. Sabemos, todos, que a obtenção da cátedra não vai ser um ponto de chegada, mas um ponto de partida que vos ensejará vôos ainda mais altos.

Que Deus vos guie, como sempre fez, nessa trajetória luminosa. 